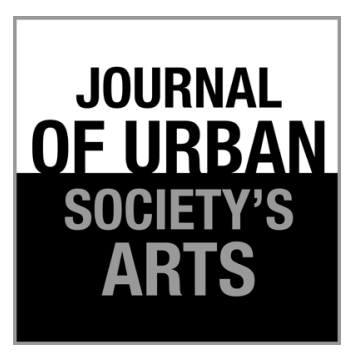

Volume 4 Nomor 1 , April 2017: 29-35

\section{Male Gaze dan Pengaruhnya Terhadap Representasi Perempuan dalam Lukisan "Realis Surealis" Karya Zaenal Arifin}

\section{Evan Sapentri}

Pengkajian Seni Pertunjukan dan Seni Rupa, Sekolah Pascasarjana

Universitas Gadjah Mada

Jln. Teknika Utara, Pogung, Sleman, Yogyakarta

Tlp.085799312700, E-mail: esapentri@gmail.com

\begin{abstract}
ABSTRAK
Penelitian ini melihat kecenderungan dan pengaruh male gaze dalam konstruksi citraan dan seksualitas dalam lukisan, dan cara si pelukis melihat atau merepresentasikan perempuan dalam lukisannya. Pengumpulan data dilakukan dengan observasi lapangan di Tahunmas Art Room Yogyakarta, wawancara mendalam dengan pelukis, serta didukung dengan kajian pustaka. Analisis lukisan realis surealis karya Arifin dilakukan melalui empat tahap yaitu: deskripsi, analisis, interpretasi, dan penilaian. Berdasarkan penelitian dapat disimpulkan bahwa lukisan menjadi salah satu media ungkap dan ekspresi diri sang seniman dalam menyampaikan dan menyematkan setiap ide dan gagasannya secara artistik. Namun, ketika perempuan dijadikan objek dalam lukisan dan diwujudkan dengan memberikan kesan yang mengarah pada pencitraan gender, tentu ini menarik untuk ditafsirkan.
\end{abstract}

Kata kunci: lukisan realis surealis; Male Gaze

\begin{abstract}
Male Gaze and It's Influence towards the Female Representation on a Painting of "Realistic Surrealist" by Zaenal Arifin. This study observes the trend and effect of male gaze in the construction of imagery and sexuality in a painting, and the ways the painter sees or represents the woman in his paintings. Data collection was done by doing the field observation in Tahunmas Art Room Yogyakarta, in-depth interview with painters, and supported by literature review. The analysis of Arifin's surrealist realist painting is done through four stages: description, analysis, interpretation, and assessment. Based on the research, it can be concluded that the painting becomes one of the expression media and self-expression of the artist in conveying and embedding every idea and thoughts artistically. However, when a woman becomes the object in the painting and is embodied by giving an impression that leads to gender imaging, this is certainly interesting to interpret.
\end{abstract}

Keywords: Surrealist realist painting; Male Gaze

\section{Pendahuluan}

Dalam dunia seni, permasalahan mengenai gender sudah sangat sering dibicarakan, baik dalam bentuk lukisan, patung, kriya, pertunjukan, serta grafis. Isu-isu gender dan perlawanan hampir tidak pernah ada habisnya untuk diperbincangkan dalam dunia seni, terutama seni rupa. Oleh sebab itu, perempuan dan dinamika berbagai bentuk ketimpangan gender sangat menarik untuk dituangkan ke dalam karya seni rupa (Edwardi 2012). Tulisan ini akan mendeskripsikan dan menganalisis karya Zaenal Arifin untuk mengamati aspek materialnya (partikelnya). Diletakkan dalam konteks semiotika, aktivitas ini adalah upaya untuk mengidentifikasi, mendeskripsi, menganalisis secara detail dan keseluruhan atas aspek penanda (signifier) suatu tanda (sign), kemudian melihat 
aspek gelombangnya dengan melihat makna, pesan, atau nilainya melalui proses penafsiran dan penilaian (Marianto 2017).

Zaenal Arifin adalah seorang pelukis kelahiran Bandung, 12 April 1955. Kehidupan Arifin sebagian besar dihabiskannya di Sumatera Utara. Arifin pernah menempuh pendidikan sarjananya pada program studi Seni Rupa Murni di STSRI "ASRI" Yogyakarta. Sampai saat ini Arifin masih rutin berkarya dan mengikuti beberapa pameran yang diselenggarakan di Indonesia maupun di luar negeri. Pameran bertajuk "Laku" ini merupakan wujud eksistensi Arifin sebagai seorang seniman, bukan semata-mata hanya untuk mencari ketenaran dalam hidup melainkan cara Arifin mampu memindahkan nilai-nilai dan perilakuperilaku positif yang disampaikannya dalam pameran "Laku" melalui sentuhan artistik ke dalam lukisannya yang ia sebut sebagai lukisan realis. Pada pameran ini, Arifin menampilkan 25 karya lukis realis. Lukisan ini sebagian besar dibuat dengan menggunakan cat akrilik dan mix media di kanvas berukuran $\pm 100 \mathrm{~cm}-200 \mathrm{~cm}$.

Mengendalikan diri bagi Arifin adalah upaya untuk menemukan ketenangan jiwa dengan rasa nrimo ing pandum (apa yang diberikan dapat diterima dengan tidak banyak protes) dan menerima rezeki dari Tuhan melalui orang-orang baik. Arifin mengatakan bahwa dirinya saat ini dan dulu itu berbeda, melukis adalah aktivitas spiritual yang dapat dijadikan nilai representasi atau cerminan hidup. Masa mudanya telah dilaluinya dengan banyak cobaan dan rintangan. Bagi Arifin kehidupan masa lalunya merupakan pelajaran berharga yang bisa diambil guna merefleksikan dan memahami makna hidup yang selama ini dijalani. Pengalaman berharga yang diperoleh mengubahnya menjadi seseorang yang sabar dan melihat perubahan hidup ini lebih arif dan bijaksana. Di umur yang sudah matang ini, Arifin banyak melakukan aktivitas yang dapat meningkatkan spritualitas dirinya, seperti: melukis, berpikir positif untuk eling lan waspodo (ingat dan berhatihati). Pada hakikatnya, bagi Arifin pencerahan diri itu sebenarnya bisa dikomunikasikan dengan cara introspeksi diri, merasakan, dan memahami diri sendiri. Berdialog diri adalah salah satu cara untuk mengubah pikiran dan perasaan dari perilakuperilaku yang negatif. Upaya melukis realis yang surealis dalam pameran yang bertajuk "Laku" ini merupakan perjalanan panjang sebagai proses kreatif untuk mengungkapkan persoalan diri dan berbagai perubahan serta peristiwa dunia untuk memahami jati diri (Raharjo 2017).

Lukisan yang diusung Arifin dalam pameran ini ia katakan sebagai lukisan realis. Realisme adalah aliran atau gaya yang memandang dunia ini tanpa ilusi, seperti apa adanya tanpa menambah atau mengurangi objek. Dalam sejarah seni rupa Barat (Eropa), proklamasi Realisme dilakukan oleh pelopor sekaligus tokohnya yaitu Gustave Courbet (1819-1877) pada tahun 1855 (Susanto 2012). Setelah Revolusi Perancis, orang tidak lagi menyukai hal-hal yang mendebarkan dan mulai menginginkan hal-hal yang wajar kemudian melahirkan aliran baru yaitu realisme (Suryana 2015).

Surealisme berawal pada abad ke-20 di Paris yang diprakarsai oleh Andre Breton, tepatnya pada tahun 1924. Surealisme pada awalnya dikaitkan dengan wacana psikoanalisis yang dikemukakan oleh Sigmund Freud, mengenai hal-hal yang irrasional, absurd, dan tidak logis. Kata surreal memiliki arti lebih dari nyata. Jika diartikan secara sederhana, segala sesuatu yang surreal merupakan sesuatu yang berasal di luar kesadaran (unconsciousness) (Kartikasari 2015). Lukisan realis surealis diartikan sebagai lukisan yang berpegang dan berdasarkan penganut paham realisme dan surealisme. Karya lukis Arifin ini mempunyai dua gaya lukis yang diyakini sebagai lukisan yang disebut sebagai lukisan realis surealis. Namun menurut saya, lukisan Arifin cenderung mendekati surealis.

Penulis memilih tiga lukisan yang merepresentasikan figur perempuan yang hendak Arifin sampaikan. Lukisan tersebut berjudul: Dialog Imajiner; Woman Power; dan Power of Love. Analisis lukisan realis surealis dilakukan melalui empat tahap yaitu: deskripsi, analisis, interpretasi, dan penilaian. Metode ini penulis adopsi dari M. Dwi Marianto dalam bukunya yang berjudul Art and Life Force in a Quantum Perspective (2017). Tulisan ini akan melihat kecenderungan dan pengaruh 
male gaze dalam konstruksi penggambaran dan seksualitas dalam lukisan realis surealis, dan cara Arifin melihat atau merepresentasikan perempuan dalam lukisannya.

\section{Pembahasan}

Korsmeyer (2004) berpendapat bahwa analisis penglihatan dan apa yang telah dikenal sebagai pandangan atau tatapan laki-laki (the male gaze), diasumsikan sebagai kemampuan untuk melihat orang lain, merupakan indikasi seksual dan kekuasaan sosial. Teori ini menekankan aktivitas penglihatan, penguasaan dan kontrol objek estetika, seperti layaknya sebuah lukisan. Ini seperti yang dialami Soekarno. Soekarno yang sejatinya seorang kolektor lukisan, tidak hanya senang dan cinta dengan rasa nikmat yang ia dapatkan ketika memandang sebuah lukisan, terutama koleksinya terhadap lukisan perempuan, bahkan ia berkata "Jika saya tidak menjadi presiden, maka saya akan menjadi seorang seniman”. Bagi Korsmeyer, perempuan diberi status yang pasif sebagai seseorang (objek) yang diperhatikan, sedangkan laki-laki adalah subjek aktif yang melihat perempuan (objek).

Posisi melihat imajinatif ditentukan oleh penonton (laki-laki). Zaenal Arifin mencoba melihat representasi perempuan yang dituangkannya dalam lukisan yang ia klaim sebagai lukisan yang realis. Analisis lukisan dilakukan melalui empat tahap yaitu; mendeskripsikan, menganalisis, menginterpretasi, dan melakukan penilaian. Menurut Marianto (2017), mendeskripsi adalah tahap awal yang penting dan fundamental. Dengan mendeskripsikan suatu objek secara detail dan menyeluruh, objek yang tadinya eksternal dari sang describer jadi terinternalisasi, sebagai bagian dari pengalaman sang descriptor. Dalam tahap ini, apapun yang dilihat akan dijelaskan secara detail dengan mencermatinya secara objektif, bisa dari ukuran karya, judul lukisan, medium yang digunakan, dan teknik yang digunakan.

Setelah melakukan deskripsi karya, langkah selanjutnya adalah dengan melakukan analisis lukisan. Pada tahap ini, objek disoroti secara detail setiap bagiannya. Menganalisis dapat dimulai dengan mengamati dan mencatat bagaimana elemen-elemen seni yang ada disusun melalui prinsip-prinsip penyusunan, guna menghasilkan suatu ungkapan pada karya seni yang dibuat. Jika mendeskripsi berpijak pada pertanyaan apa (what), maka dalam menganalisis berpijak pada pertanyaan bagaimana (how) (Marianto 2017). Tahap selanjutnya adalah menginterpretasi dan menilai seni. Pada tahap ini, peneliti mulai menunjukkan makna apa yang menyembul dan menyeruak dalam lukisan. Oleh sebab itu, kejelian dalam melakukan pengamatan sangat memengaruhi hasil interpretasi terhadap lukisan. Proses untuk mencermati pandangan Arifin (seniman) kaitannya dengan bentuk representasi perempuan, akan diperoleh dengan menganalisis tiga lukisan berikut (Gambar 1).

Karya Zaenal Arifin yang berjudul Dialog Imajiner merupakan karya lukis yang dibuat dengan menggunakan cat akrilik pada kanvas, berukuran $200 \mathrm{~cm} \times 150 \mathrm{~cm}$, yang dibuat pada tahun 2012 . Dalam karya ini terdapat dua orang wanita yang bisa dikatakan kembar; yang membedakan hanya atribut yang dikenakan. Kedua figur perempuan digambarkan dengan membawa senjata berupa pistol. Ekspresi wajah yang digambarkan sebagai perempuan yang centil, genit, dan sedikit manja dengan bibir yang ditonjolkan seakan sedang melakukan dialog. Rambut hitam pekat terurai menjuntai di bagian punggung seolah-olah diikat, karena tampak rapi terurai. Bahu dan tangan yang seksi digambarkan terbuka dengan menampilkan pakaian dalam. Seutas tali putih menjuntai yang

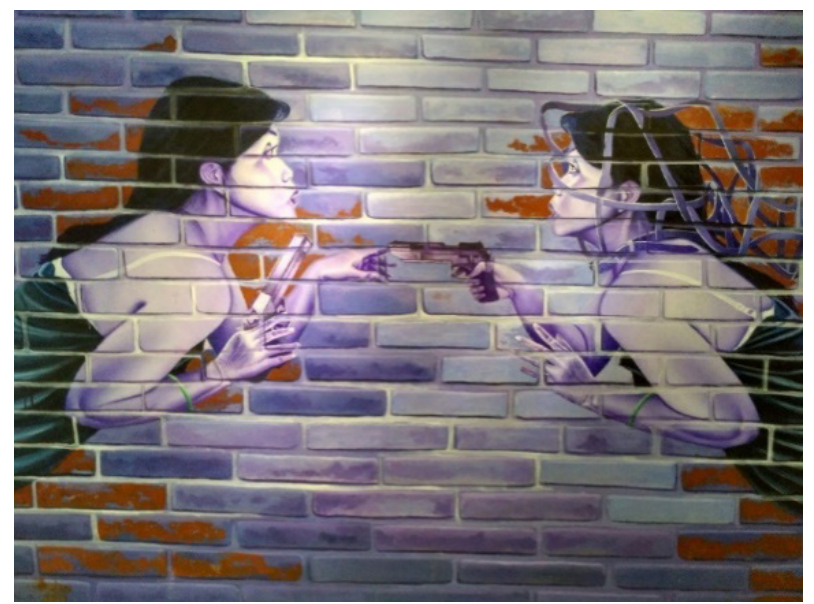

Gambar 1. Dialog Imajiner karya Zaenal Arifin Cat minyak di atas kanvas, $200 \mathrm{~cm} \times 150 \mathrm{~cm}, 2012$

(Foto: Evan Sapentri, 2017) 
dihubungkan dengan pakaian luarnya berwarna hitam, sementara itu, tangan kanan memegang pistol berwarna hitam (figur wanita sebelah kanan), disambut dengan tangan kiri (figur wanita sebelah kiri) yang tampak seksi gerakannya. Menarik ketika Arifin menambahkan semacam kerangka (besi) yang melilit kuat tepat di kepala figur perempuan sebelah kanan (Kartika 2015).

Arifin memilih tembok sebagai latar belakang karya di setiap lukisannya yang merupakan cerminan perubahan baginya. Tembok bisa dikatakan sebagai benda yang memisahkan antara ruang dan waktu. Tembok sebagian besar terbuat dari beberapa material pendukung seperti bata (tanah liat), batako, adonan semen, dan lain-lain. Layaknya sebuah kehidupan di dunia ini, tembok dijadikan sebagai simbol peradaban umat manusia, simbol perubahan-perubahan yang terjadi di dunia ini, simbol tempat bercermin diri, introspeksi diri, simbol perjalanan hidup dan pengembaraan hidup manusia. Tembok juga bisa dikatakan sebagai pembatas, pelindung, dan merupakan salah satu elemen penyusun sebuah ruang atau gedung. Tentu dalam setiap penggembaraan hidup di dunia akan selalu mengalami perubahan diri karena dipengaruhi banyak hal bisa dari faktor sosial, budaya, ekonomi, bahkan politik dari sebuah negara.

Arifin tetap menunjukkan perempuan sebagai seseorang yang cantik, menawan, seksi, dan menggoda. Dialog Imajiner merupakan judul yang tepat untuk merepresentasi perempuan saat ini. Ada dualitas yang terlihat ketika ia menyandingkan dua objek penting di sini, yaitu perempuan dan pistol. Bagi saya, perempuan bisa dikatakan sebagai seseorang yang mempunyai sifat, sikap, dan hati yang lembut, sedangkan pistol diimpresikan sebagai wujud atau simbol kekuatan, ketangkasan, dan "mungkin" tidak selayaknya dimiliki oleh seorang perempuan. Namun, disini saya melihat bahwa, Arifin sangat cerdik ketika menggunakan dualitas itu. Arifin ingin menunjukkan bahwa, tidak selamanya indikasi-indikasi yang merujuk pada sesuatu yang mempunyai kekuatan, ketangkasan, mengarah kepada laki-laki. Ia ingin menggambarkan bahwa perempuan juga bisa independent, kuat, dan santun. Dialog Imajiner ini sebagai simbol bahwa perempuan itu pintar dan cerdas, mampu bernegoisasi dengan dirinya secara arif dan bijaksana.

Wujud pemberontakan mengenai perempuan telah banyak disinggung dan diperbincangkan, seperti dalam film Bandit Queen, dimana Phoolan Devi digambarkan sebagai sosok perempuan dari kasta rendah yang berani melawan dirinya dan konstruksi sosialnya, hingga menjadi pemimpin geng bandit dan meneror beberapa kota di India (Buikema and van der Tuin 2007). Hal inilah yang ingin Arifin angkat, namun ia tetap memperhatikan kaidah dan aturan mengenai perempuan yang dilukiskan. Dua figur perempuan yang dilukisakan kembar atau identik ini sebagai wujud refleksi atau cerminan diri seorang perempuaan masa kini. Pasalnya, ini berkorelasi dengan tema "Laku" yang diusung dan latar belakang tembok yang dipilih Arifin. Perempuan sejatinya mampu bercermin diri, membongkar imajinasi diri, dan tidak mau dikekang dengan ilusi. Ketika kepala dikunci dengan besi yang melilit, kemudian pistol yang siap meluncurkan peluru, dengan dahyat mampu menembak akal atau pikiran perempuaan masa kini. Perempuan sebagai seorang yang terbuka pikirannya, mampu menerima masukan, kritikan, dan akan selalu berbenah diri. Kekuatan dan kelembutan inilah yang dijadikan Arifin sebagai dualitas untuk membangkitkan semangat perempuan dalam meraih impiannya. Kompromi diri dan mawas diri terwujud dalam Dialog Imajiner, yang mengacu pada pandangan yang sebatas hanya angan-angan, bukan yang sebenarnya. Namun, bagi saya yang terpenting adalah, ketika Arifin mampu mewujudkan sesuatu yang imajiner itu muncul sebagai sesuatu yang tampak, dengan menggunakan pistol sebagai simbol kekuatan untuk meledakkan (otak dan pikiran) yang imajiner itu (Hidajat 2015).

Woman power, sekilas apakah sebagai bentuk penghormatan terhadap perempuan atau justru sebaliknya? Menarik ketika Arifin menyuguhkan lukisan tersebut dan memperlihatkan perempuan yang seolah-olah sedang bertindak dan bersikap ketika ia dihadapkan dengan sesuatu yang mempunyai daya/kekuatan. Raungan harimau yang digambarkan semacam penyebab kegaduhan ini 
membuat sosok (perempuan) terlihat menenangkan sang harimau dengan mengangkat telunjuknya sebagai simbol diam, layaknya seorang ibu yang menenangkan anaknya yang sedang menangis.

Produksi media terhadap citra perempuan beberapa tahun terakhir ini menunjukkan perkara ketubuhan perempuan saja. Perempuan dianggap sebagai sosok yang anggun dan cantik. Gambaran perempuan sebagai objek seksual, hampir tidak pernah berubah. Penampilan terhadap perempuan sebagai sang penggoda ketimbang sebagai yang digoda. Dalam hal ini adanya image masyarakat bahwa tanpa perempuan seksi tidak akan berlangsung proyek desakralisasi seks yang dibutuhkan untuk menciptakan masyarakat konsumtif yang boros dan mengejar kepuasan belaka (Farihah 2013).

Perempuan yang mementingkan diri sendiri telah menginternalisasi pandangan pengamat di tubuh mereka dan secara kronis memonitor diri mereka sendiri untuk mengantisipasi bagaimana orang lain menilai penampilan mereka, dan kemudian memperlakukannya sendiri (Calogero 2004). Dalam hal ini, Arifin tidak hanya mempersoalkan perihal tubuh, melainkan bagaimana perempuan mampu berbicara melalui tubuhnya. Bukan persoalan sensual saja, namun bagaimana perempuan membawakan diri ke ranah fungsi. Maksudnya, langkah-langkah atau tindakan apa sajakah yang akan dilakukan perempuan ketika berada dalam situasi dan kondisi tertentu dalam dunia ini.

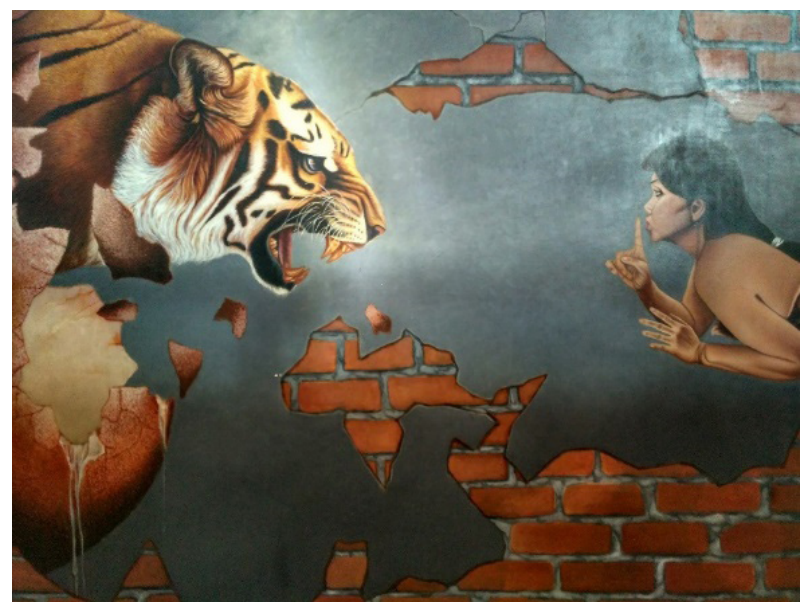

Gambar 2. Woman Power karya Zaenal Arifin Cat minyak di atas kanvas, $200 \mathrm{~cm}$ x $150 \mathrm{~cm}, 2014$

(Foto: Evan Sapentri, 2017)
Arifin ingin menyematkan kekuatan perempuan melalui lukisannya. Pertanyaannya, kenapa harimau yang disandingkan dengan perempuan? Apa yang Arifin lihat dan bagaimana ia memandangnya? Harimau adalah binatang buas pemakan daging, dan bisa dikatakan bahwa harimau merupakan penguasa hutan yang ditakuti banyak binatang lain yang hidup di hutan. Harimau sebagai simbol sesuatu yang ditakuti, dihormati, dan disegani. Ini berkaitan, perihal siapa yang ditaklukkan dan siapa yang menaklukkan. Saya berpendapat bahwa harimau dijadikan sebagai simbol kejantanan seorang pria, simbol kekuatan, dan penakluk (dalam hal ini adalah perempuan). Muncul pertanyaan lagi, lantas mengapa sang harimau tetap meraung ketika perempuan itu menunjukkan simbol diam? Atau justru di sini pesan penting yang hendak ia sampaikan? Memang perempuan itu menunjukkan usahanya untuk membuat harimau diam.

Arifin sangat bijak ketika menggambarkan perempuan sebagai sosok yang pantang menyerah dan tetap berusaha keras. Perempuan merupakan seseorang yang jeli, ulet, dan mandiri. Ia mampu menenangkan dan memberikan rasa aman dan nyaman terhadap lingkungan sekitar. Kembali pada lukisan Woman Power, apakah mungkin jika perempuan di sini diartikan sebagai seorang penakluk laki-laki? Lantas, laki-laki yang manakah? Laki-laki disimbolkan sebagai sang harimau, dan secara langsung Arifin mengambarkan perempuan dilukisan ini. Konteksnya, Arifin adalah seseorang yang melukis sekaligus sebagai penikmat lukisan ini. Perkara ini, bisa saja sebagai media ungkap sang seniman dalam merepresentasikan peran perempuan dalam kehidupan rumah tangganya.

Power of Love (kekuatan cinta) merupakan karya lukis yang dibuat dengan menggunakan cat minyak, dengan ukuran $200 \mathrm{~cm} \times 150 \mathrm{~cm}$, dan dibuat pada tahun 2012. Dalam lukisan ini, Arifin tetap menghadirkan perempuan dan harimau. Namun, perempuan digambarkan dengan memegang bunga mawar merah yang merekah, sedangkan kepala harimau diberikan kerangka (besi) yang tampak terikat kuat. Mulut sang harimau terlihat menganga dan seperti terusik dengan kehadiran perempuan. Saya berpendapat 
bahwa lukisan yang berjudul Power of Love ini masih berkorelasi dengan lukisan yang berjudul Women Power. Perempuan diletakkan sebagai subjek dalam lukisan, perempuan sebagai figur yang cukup mendominasi dan memiliki peran yang lebih signifikan dibandingkan sang harimau.

Bunga mawar dijadikan simbol cinta yang mengarah kepada objek harimau. Arifin merasa bahwa perempuanlah yang mempunyai daya (cinta) yang sesungguhnya. Perempuan mampu menaklukkan emosi dan amarah yang meluap, ketika sang harimau meraung. Kehadiran perempuan dalam lukisan ini menarik, apalagi ketika ia berbicara melalui tubuhnya. Gerak badan dan ritme tubuh terlukiskan secara eksplisit, namun kekuatannya sangat dahsyat dan jelas terlihat dalam lukisan tersebut.

\section{Simpulan}

Zaenal Arifin sampai saat ini masih rutin berkarya dan mengikuti beberapa pameran yang diselenggarakan di Indonesia maupun di luar negeri. Pameran bertajuk "Laku" ini merupakan wujud eksistensi Arifin sebagai seorang seniman, bukan semata-mata hanya untuk mencari ketenaran dalam hidup, melainkan bagaimana Arifin mampu memindahkan nilai-nilai, sifat, dan perilaku-perilaku positif yang disampaikannya dalam pameran melalui sentuhan artistik ke dalam lukisannya yang ia sebut sebagai lukisan realis.

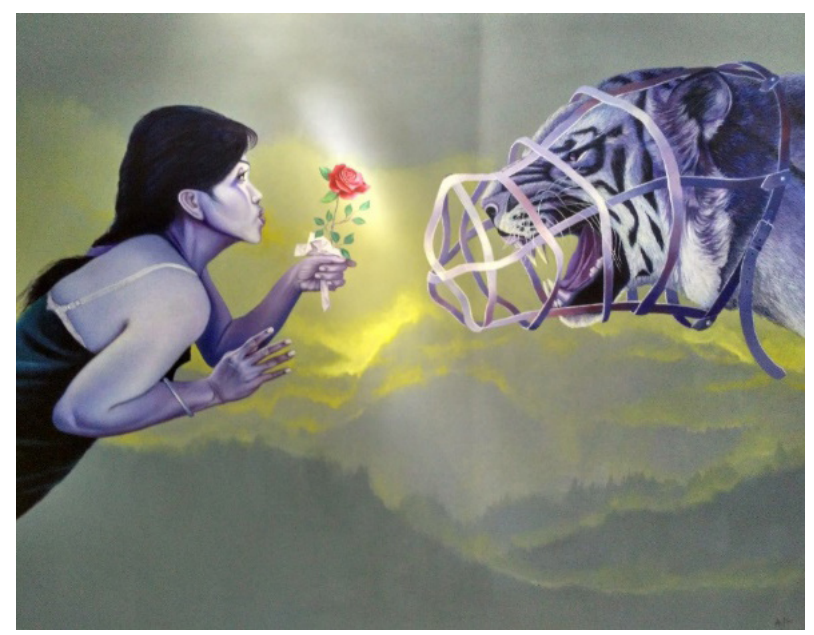

Gambar 3. Power of Love karya Zaenal Arifin Cat minyak di atas kanvas, $200 \mathrm{~cm} \times 150 \mathrm{~cm}, 2012$ (Foto: Evan Sapentri, 2017)
Wujud dari pandangan atau tatapan laki-laki (the male gaze) terlihat ketika Arifin merepresentasi perempuan sebagai subjek untuk membicarakan perihal tubuh dan ketubuhannya. Dalam lukisan yang berjudul Dialog Imajiner; Women Power; dan Power of Love, Arifin menunjukkan peran perempuan sebagai figur yang independen, kuat, dan santun. Perempuan sebagai seseorang yang terbuka pikirannya, mampu menerima masukan, kritikan, dan akan selalu berbenah diri. Kekuatan dan kelembutan inilah yang dijadikan Arifin sebagai dualitas untuk membangkitkan semangat perempuan dalam meraih impiannya.

\section{Ucapan Terima Kasih}

Penulis mengucapkan terima kasih kepada Zaenal Arifin, S.Sn. (seniman) yang telah memberikan izin melakukan wawancara sehingga penelitian ini dapat terlaksana dan Prof. M. Dwi Marianto, M.F.A., Ph.D. yang telah membantu dalam menyempurnakan tulisan ini sehingga artikel ini dapat diterbitkan.

\section{Kepustakaan}

Buikema, R, and I van der Tuin. (2007). Doing Gender in Media, Art and Culture. London: Routledge Taylor \& Francis Group.

Calogero, Rachel M. (2004). "A Test of Objectification Theory: The Effect of the Male Gaze on Appearance Concerns in College Women."” Psychology of Woman Quarterly: 16. Edwardi, Fariko. (2012). "Protes Perempuan Terhadap Konstruksi Gender Dalam Karya Lukis.” [Tesis] Universitas Negeri Padang. Farihah, Irzum. (2013). "'Seksisme Perempuan Dalam Budaya POP Media Indonesia.” Jurnal PALASTREN 6(1): 225.

Hidajat, Robby. (2015). "Sungai Sebagai Transmisi Ritual Urban Kesuburan Melalui Pertunjukan Wayang Topeng." Journal of Urban Society's Arts 2(1): 1. http://journal.isi.ac.id/index. php/JOUSA/article/view/1264.

Kartika, Bambang Aris. (2015). "Mengapa Selalu Harus Perempuan: Suatu Konstruksi Urban Pemenjaraan Seksual Hingga Hegemoni 
Maskulinitas Dalam Film Soekarno.” Journal of Urban Society's Arts 2(1): 35.

Kartikasari, Novia Nur. (2015). "Surealisme Dan Metafora Dalam Kolase Visual Thief Karya Resatio Adi Putra.” [Tesis] Universitas Gadjah Mada.

Korsmeyer, Carolyn. (2004). Gender and Aesthetics: An Introduction. New York: Routledge Taylor \& Francis Group.

Marianto, M. Dwi. (2017). Art and Life Force in a Quantum Perspective. Yogyakarta: Scritto Books Publisher.
Raharjo, Timbul. (2017). "Kurator Laku Di Tahunmas Art Room, Kasongan, Bantul, Yogyakarta."

Suryana, Jajang. (2015). Tinjauan Seni Rupa. Yogyakarta: Graha Ilmu.

Susanto, Mikke. (2012). Diksi Rupa: Kumpulan Istilah Dan Gerakan Seni Rupa. Yogyakarta: DictiArt Lab \& Djagad Art House.

\section{Informan}

Zaenal Arifin (Seniman) 